\title{
NEW YORK'S PROPOSED SIMPLIFIED PRACTICE
}

\section{ACT}

\section{HISTORY OF NEW YORK PRACTICE ACTS}

The common law procedure of England was accepted by New York upon entering upon its existence as a commonwealth. In I848, the Code of Procedure, known as the Field Code, was adopted, thereby introducing substantial changes in the common law practice. Later, in 1877 and 1880 , the two parts of the present Code of Civil Procedure, now consisting of more than 3,300 sections, were adopted, thus bringing together matters relating to procedure, whether substantive or otherwise, and practically all details of practice were thereby regulated by statutory enactment, except that in addition there are various general rules of practice, and also local statutes and rules governing inferior courts.

Those not familiar with actual conditions in a large city like New York, must necessarily draw upon their imagination and endeavor to picture, for example, the trial and special terms of the supreme court in New York county (or Borough of Manhattan), where 6 parts or court rooms are devoted to the trial of actions without jury, 20 parts to jury trials, one part to $e x$ parte business and one part where as many as Ioo to I5O, and more, "contested" motions are on the calendar every day. In addition, there is the appellate division of the supreme court and the appellate term, and also the various trial and special term parts of the city court as well as nine district municipal courts having jurisdiction of actions involving $\$ I, 000$ or less, some of these also having a number of trial parts each day. Relative conditions exist in other counties within the present City of New York. It is not to be expected, therefore, that the present system of procedure is entirely satisfactory. Indeed, one might imagine that it could hardly be expected that any system of procedure could be devised which would work satisfactorily under such conditions.

Since 1895 , commissions and committees have, from time to time, been appointed, official and unofficial, all of which have met and adjourned, some have considered and reported or forgotten to report, until now the official Board of Statutory Consolidation has drafted and submitted to the legislatire its report 
on the simplification of the civil practice. A joint committee of the legislature now has the matter under advisement, and it is doubtful whether the proposed new act, or any substituted act, will reach the legislature for vote, before rgr7. This is well, as the widest possible debate should precede the final adoption of a new practice act.

\section{STRUCTURE OF THE PROPOSED ACT}

The proposed act consists of 7 I sections, which are largely recommendations of what is regarded as ideal rather than commands as to procedure. Large portions of the present Code of Civil Procedure, while not abolished, have been given less "practical" aspect by being turned into the Consolidated Laws, which are equivalent to the revised statutes or revised laws as known in many of the states. It is this practice act of $7 \mathrm{I} \mathrm{sec-}$ tions which it is intended shall be the creature of the legislature, but in order to prescribe more or less detail for the practice, the Board has also prepared 4OI rules, which in the first instance shall also be enacted by the legislature, but thereafter are to be 'in the hands of the courts, so that the control of and responsibility for procedural matters shall be in the hands of the courts.

FEATURES OF THE PROPOSED PRACTICE

Only the main features of the act and rules can be referred to, and in order to avoid repetition, the present or past tense will be frequently employed, thus treating the matter as if the act now existed. There is to be but one form of action $(\$ 4)$; mistakes, irregularities or defects, not affecting a substantial right are to be disregarded, ( $\S I 0)$; costs are discretionary, ( $(I 5)$; any number of causes of action or counterclaims may be set up in the same complaint or answer, ( $(19)$, and great liberality in the joinder of parties is also permitted, $(\S 20)$; the demurrer is abolished and all relief for defective pleading shall be by motion, ( $\$ 27)$; trial without a jury is made the normal mode of trial, and trial by jury must be specifically demanded or is waived, "but a jury trial may be had, by order, of any issue of fact notwithstanding such waiver, or a jury trial may be dispensed with by order, in a case where the right to dispense with a jury trial now exists," ( $\$ 34)$; the practice of taking exceptions to rulings, verdicts, reports and decisions is discontinued, $(\$ 35)$; the unconditional dismissal of a complaint or 
counterclaim at the close of the evidence is to be regarded as on the merits, unless stated to be without prejudice to a new action, $(\$ 36)$; except by consent of the court, appeals from intermediate decisions in the nature of the existing interlocutory judgment, are limited to the appeal from the final judgment, $(\$ 48)$; an order takes the place of an interlocutory judgment (Rule 37), and there is to be but one judgment.

Special proceedings, such as mandamus, prohibition, for the appointment of a committee of an incompetent, for the sale, mortgage or lease of an infant's or incompetent's real property, and the like, are abolished, and all such are to be actions, to be commenced by summons and complaint. The Constitution preserves the right to habeas corpus in certain cases and the proposed practice act naturally makes no attempt to abolish any constitutional right. Again, the special proceeding "writ of assessment of damages" under which the state or the United States acquires real property, is retained as a special proceeding. Other efforts to abolish special proceedings entirely also became impossible, as for example, a proceeding to change one's name. Who could be the plaintiff and defendant if that proceeding were converted into an action? So that also is retained as a special proceeding. The procedure in such special proceedings is, however, prescribed by the Consolidated Laws.

\section{NEW FORM OF PROCESS}

Two forms of summons for the commencement of an action are provided. One is the general form of summons to answer, with which the profession in New York is familiar, and under which the defendant is called upon to answer the complaint in twenty days or suffer judgment by default. The other is a new form to be called "summons to appear." Under this new form, the defendant is required to appear in court or before a judge, at a specified time, not less ${ }^{1}$ than eight days from the service, unless a shorter time is prescribed by endorsement on the summons. The summons to appear may be used where the plaintiff seeks only to recover a debt in the nature of a sum certain, arising upon contract, bonds, statutes, warranty or on a trust, in summary proceedings and in "cases specifically provided for." (Rule 86.) The procedure on the return day of the summons

'The proposed rules say "more" which evidently is intended for "less." 
is not prescribed and there is not even any requirement that the plaintiff must serve a complaint with the summons. Rule 305 authorizes the court to direct judgment on the return day or order a reference or a trial, or make such other disposition as the case may require "unless it appears that the defendant is entitled to defend," which may mean that in a case where the summons to appear is authorized, the defendant, on the return day, must show his hand, volunteer his proof and argue his case, before he may be permitted to interpose an answer.

\section{PLEADINGS AND SERVICE OF PROCESS}

The answer and the reply are "to point out the actual issues." ( $\$ 26$, and Rules I4I et seq.) The present provisions for substituted service and service by publication have been partly stripped of their technical character. The present provision of the Code of Civil Procedure is also retained, which permits service without the state, with a judge's order, in certain instances where the action affects title to real or personal property. (Rule 2I7.) On the other hand, where the action relates to real property and service is had by publication, the published notice shall also contain a brief statement of the object of the action and a brief description of the property. (Rule 215.) A similar provision is in the present Code of Civil Procedure as to actions for partition. Since September I, I9I4, the authorized charges for publishing legal notices have been practically doubled by statutory amendment, and this additional requirement would merely add further to the cost of service by publication. In fact, the whole system of publication might well be abolished and mailing alone substituted, except where the defendants or their residences are unknown. A fiction of the law alone enables us to suppose, however, with suppressed amusement, that an unknown defendant, last heard of in Australia, will, except by pure accident, receive notice by a summons published in a local newspaper in Brooklyn or in Buffalo.

\section{MOTION FOR DIRECTIONS}

In an effort to prevent the making of many preliminary motions, such as for bill of particulars, to make the pleadings more definite, discovery, interrogatories, etc., a motion for directions is provided and is to be made within fourteen days after the action is at issue, and the decision of the judge thereon is to 
be embodied in a single order. (Rule 24I.) This does not, however, prevent the making of subsequent motions, but may subject the dilatory party to costs.

\section{APPEALS AND EXECUTION}

An appeal shall be in the nature of a rehearing. It is unnecessary to take a formal exception to rulings but objections must still be taken. The appellate courts are authorized in certain cases to take additional evidence, but not in contravention of any constitutional right. "In case a new trial is granted it shall only be a new trial of the question or questions with respect to which the verdict or decision is found to be wrong if separable. When a new trial is ordered because the damages are excessive or inadequate and for no other reason, the verdict shall be set aside only in respect of damages, and shall stand good in all other respects." (Rule 33I.) The stenographer's minutes of the trial (not necessarily all) are to be used as the basis of the case on appeal and the testimony is not to be reduced to narrative form. The appellant is also required, when he serves his proposed case on appeal, to serve a statement of the questions he proposes to raise on the appeal. This latter can hardly be said to be an improvement, as the appellant would, undoubtedly, include in his statement every conceivable, if not also inconceivable, question which could be raised. Proceedings supplementary in aid of enforcing the judgment have been simplified to make possible more direct results and to make subsequent judgment creditor's actions unnecessary.

\section{SUMMARIZED ARGUMENTS, PRO AND CON}

- As it has been possible to present scarcely more than a summary of the more important features of the proposed act and rules, so it will be possible to refer only in the most general way to the arguments for and against the change, though the temptation to linger over the arguments is more than alluring. The arguments generally advanced against regulating details of practice by statute are: (I) tinkering by inexperienced legislators; (2) possibility of amendment to suit individual cases; (3) statutes bind courts to rigid rules; (4) promote contests over minor points of practice; (5) the responsibility for the administration of justice is placed upon the courts while the control is given to the legislature. On the other hand, objection 
is made to giving courts the power to regulate details of practice because, it is said, it would be unwise to place such unlimited power in the hands of the courts. Yet it must be admitted that the courts are daily making the law with reference to substantive matters. In fact, in whose mind does not linger that terse definition absorbed in the early days of law-school life, that "the common law is that body of the law which is judgemade law as distinguished from the law enacted by the legislature,"-that paradoxical lex non scripta, which, theoretically unwritten, might yet be read in the law reports as written by the judges. ${ }^{2}$ It must be conceded, of course, that the promulgation of substantive law is theoretically based upon principles of right and wrong, while rules of procedure are, on the contrary, always more or less arbitrary, and that therefore the champions of either side may prolong their disagreement as to whether the courts or the legislature would be more tender in exercising arbitrary powers.

Then, there are those who assert that after reading the proposed practice act and rules, and the transpositions into the Consolidated Laws, they turn away with the impression that the present Code of Civil Procedure has to a large extent simply been re-edited, and greater power given to the courts to regulate details of practice in the future.

There are, however, radical changes, such as the provisions for the new form of summons to appear, the liberalizing of the joinder of parties and causes of action, the abolishing of the demurrer, the attempted simplification in pleading, and in reaching results after judgment. Most of these changes, if not all, are generally regarded as commendable. It may be debatable whether proceedings for the sale of an infant's or incompetent's real property, and similar proceedings, may be conducted in the form of an action, with any more practical feasability than in the present form. So also, it is proposed to make the right of appeal from an intermediate decision depend upon the consent of the court $(\$ 48)$, failing in which, the only appeal would seem to be from the final judgment. Great hardship may thus result in some cases. For example, in partition, the inter-

\footnotetext{
"No inclusive definition of the "common law" is intended by these observations. They are general only, as it must be recognized that in the use of the expression there is sometimes included portions of the statute law of England as it existed prior to the adoption of the common law in some of the states of the Union.
} 
locutory judgment directs the sale of the property and this interlocutory judgment is now to be an intermediate order. If the order for the sale of the property is erroneous, and the court refuses to allow an appeal, the aggrieved party must stand by and see his property sold, perhaps at a sacrifice and when he does not want it sold at all, and then wait for the final judgment and appeal therefrom. Meanwhile, however, his property has been sold and perhaps the very thing he sought to prevent by his appeal, has taken place. There could be little satisfaction or consolation for such a suitor in having the order for the sale reversed on appeal.

There is still another position which those take who are willing to assume that some of the proposed changes are worthy of adoption, but who maintain that it resolves itself into the question whether the bar favors the entire repeal of the present Code of Civil Procedure, or whether the same results could be as satisfactorily obtained by amending the present Code so as to adopt some of the new acceptable features suggested by the Revisors.

Of the New York Bar.

Fred L. Gross. 